\title{
Inter- and Transdisciplinarity
}

\author{
Michael Prytula, Tobias Schröder, and Harald A. Mieg
}

How does inquiry-based learning work in interdisciplinary, practical teaching contexts? This chapter presents examples of interdisciplinary inquiry-based learning and the associated basic conditions. The conclusion is comprised of three theses. We claim that interand transdisciplinarity require a new unity of teaching and research.

\subsection{Social Transformation Processes and Their Consequences for Scholarship and Higher Education}

Global development is characterized by many challenges that elude categorization by academic discipline. Examples include not only climate change and increasing urbanization, but also terrorism, ensuring food security and the integration of the Internet into industry and society. The processes of change are mutually interdependent and have an impact in a global, regional and local context, e.g. in day-to-day issues of urban development and urban management.

Social transformation processes are characterized by what have been referred to as "wicked problems," which cannot be described by clearly specifiable actual and target states, and the solutions to which always contain normative valuations ("what should we do

M. Prytula, Prof. Dr.-Ing. $(\bowtie) \cdot$ T. Schröder, Prof. Dr. Dipl.-Psych.

Fachhochschule Potsdam, Institut für angewandte Forschung Urbane Zukunft,

Potsdam, Germany

e-mail: prytula@fh-potsdam.de; schroeder@fh-potsdam.de

H. A. Mieg, Prof. Dr.

Humboldt-Universität zu Berlin, Georg-Simmel-Zentrum für Metropolenforschung,

Berlin, Germany

e-mail: harald.mieg@hu-berlin.de

H. A. Mieg (ed.), Inquiry-Based Learning - Undergraduate Research, 
and what do we want to do?"). We often find ourselves dealing with contradictory goals and heterogeneous bodies of knowledge (Wissenschaftsrat 2015, p. 16). Urban district development and efforts to achieve social peace in cities provide much-discussed examples.

Given these challenges, time and again, scholarship requires rethinking that goes beyond disciplinary boundaries. Approaches to this take different names (cf. Schneidewind and Singer-Brodowski 2014), e.g. "Mode 2," "transdisciplinarity" or the "co-production of knowledge." What all of these approaches have in common is that (1) interdisciplinary collaboration is regarded as necessary and (2) dialogue with society is sought.

\subsection{Challenges in Inter- and Transdisciplinarity in Inquiry-Based Learning}

Interdisciplinarity is not a new requirement. It comes to the forefront again and again because working within disciplines has become established over the centuries as the "operating condition" of sciences (Mieg and Evetts 2019). Collaboration across the disciplines can take various forms:

- Multidisciplinary refers to the collaboration that occurs when different disciplines work alongside each other on a project. This can be considered the normal case for research projects that span multiple disciplines.

- Project work is interdisciplinary when the disciplines are essentially dependent on the mutual exchange of methods or results. Interdisciplinary work is more commonly found in practice than in scholarship, e.g. large construction projects require the integration of technical, architectural, infrastructural and landscape planning aspects.

- Transdisciplinary refers to collaboration that goes beyond disciplines. Sometimes the term is used to denote increased interdisciplinarity, i.e. finding a common language and superordinate approach. Other times, the term is interpreted as the inclusion of social groups outside the university. Hereinafter, we will assume the latter definition of transdisciplinarity.

The concept of transdisciplinary teaching includes a determination of types of knowledge, towards which inquiry-based learning must be oriented. Corresponding teaching projects were developed in Switzerland in the 1990s (cf. Mieg et al. 2001; Scholz and Tietje 2002). It makes sense to distinguish between three types of knowledge (cf. Schneidewind and Singer-Brodowski 2014):

- Systems knowledge, which describes knowledge about complex systemic connections (knowledge about what is);

- Target knowledge or knowledge about evaluation, which asks how normative assumptions can be justified (knowledge about what should and should not be);

- Transformation knowledge, which is needed in order to reach new goals and intentions (knowing how to get from the actual state to the desired state). 


\subsection{Case Study: InterFlex Seminar, "Visionen Urbaner Zukünfte" ("Visions of Urban Futures") at the University of Applied Sciences Potsdam}

In the following, we will take a specific course as an example in order to illustrate our ideas about mediating interdisciplinary and transdisciplinary competencies within the context of urban transformation, utilizing methods of inquiry-based learning.

The project seminar, "Visionen Urbaner Zukünfte - Leitbildprozess Potsdam" ("Visions of Urban Futures - Urban Development Guidelines for Potsdam"), which is presented here in detail, was held within the context of the "InterFlex" teaching format (see Box 11.1). The project seminar serves as a model for the interdisciplinary and transdisciplinary master's degree program "Urbane Zukunft" ("Urban Future"), which was then being

\section{Box 11.1: What Is InterFlex? (Diemut Bartl)}

InterFlex is a regular teaching format that is open to all students at the University of Applied Sciences Potsdam, which connects interdisciplinary teaching with research. It allows students to come into contact with real fields of research even before completing their studies and, in so doing, to investigate their own questions, often in interdisciplinary teamwork with the help of inquiry-based learning. Participants are intermixed in terms of discipline due to the interdisciplinary course, and are supported by an equally interdisciplinary teaching tandem team consisting of at least two educators.

An example of an InterFlex course is "People - Migration - Memories. What historical migratory movements lie buried in family history?" ("Menschen Migration - Memorien. Welche historischen Migrationsbewegungen verbergen sich hinter der Geschichte von Familien?"). The project, on which the disciplines of archive studies and social studies cooperated, ran for two semesters from 2010 to 2011 and struck a nerve with many students, who devoted themselves with research and scientific work to the ever-present phenomenon of flight, migration and displacement and, in doing so, grappled with their own family histories. The result was an interactive digital map that documented the migratory movements and the various reasons for leaving home with the help of official and private documents.

InterFlex is based on the "Exzellente Lehre" ("Excellent Teaching") competition tender for 2009 and was financed from 2010 until the end of 2013 by funding from the Stifterverband der Deutschen Wissenschaft (German Association of Donors for the Promotion of Sciences and Humanities) and the Ministry for Science, Research, and Culture of the State of Brandenburg. The university has continued to fund the project since 2014. To date, more than 80 teaching-research courses have been created within the context of InterFlex and 50 percent of educators and more than 1500 students have been involved (cf. Ammann et al., 2013). 
developed at the University of Applied Sciences Potsdam (FHP). The course was attended by students in FHP degree programs in architecture and urban development, cultural advancement, design, and information science. The two educators represented the disciplines of architecture and social psychology, respectively, and introduced actively ongoing research (Prytula 2011; Schröder et al. 2011; Wolf et al. 2015). The project seminar took place in cooperation with the participatory process of developing policy guidelines for the city of Potsdam (Landeshauptstadt Potsdam 2015). In the course, the students examined visions and models of future urban development from the perspective of architecture and urban planning on the one hand, and from the perspective of social psychology in terms of the processes and mechanisms of action on the other. By visions we refer to the mental representations of future conditions shared by agents in a social system, which are emotionally appealing and cognitively persuasive. If they inspire the agents in a social system and motivate them to coordinate their activity towards a common goal for the future, visions can serve as powerful building blocks in processes of change (cf. Nanus 1992).

A central component of the seminar was the cooperation with the regional capital of Potsdam and the simultaneously occurring process of developing new policy guidelines, "Rethinking the Future of Potsdam" ("Potsdam weiterdenken," cf. Landeshauptstadt Potsdam 2015). The citizens of Potsdam were involved in the discussion about the strategic goals for the future development of Potsdam in an inductive participatory process. The goal of the process was, in particular, to make urban changes and growth processes sustainable, to coordinate the multitude of sub-strategies and concepts in regional capital, and to ensure its long-term financial performance. The task of the students was to develop and prepare their own project ideas based on the topics specified by the citizens. The student projects were discussed with representatives of the city administration and finally presented as poster presentations and in a final report (see Fig. 11.1 for examples).

While the project work carried out in small groups was a central thread for students throughout the semester, we supported the working process purposefully with methodological and theoretical basic knowledge in four consecutive thematic fields:

1. Basic principles of visioning: To begin with, we asked: based on the current state of social psychological research, what are visions, how and when do they exert an effect, and what distinguishes successful visionary processes from failing ones? Inter alia, the basic principles with regard to values, milieus and lifestyles, power and influence processes, as well as concepts of transformational leadership in a management context, were developed and discussed with students.

2. Architecture of a vision process: The students were then instructed to think through their own chosen project topic systematically with the help of a structured vision process. In so doing, they were to fall back on a process model of visionary leadership known within the context of organizational change management (Nanus 1992), which the two course instructors had adapted to the context of urban transformation processes.

3. Methods of futurology: In the third thematic block, basic principles concerning complex systems were taught and some methods of futurology were presented by way of example such as 


\section{einPotsdam}
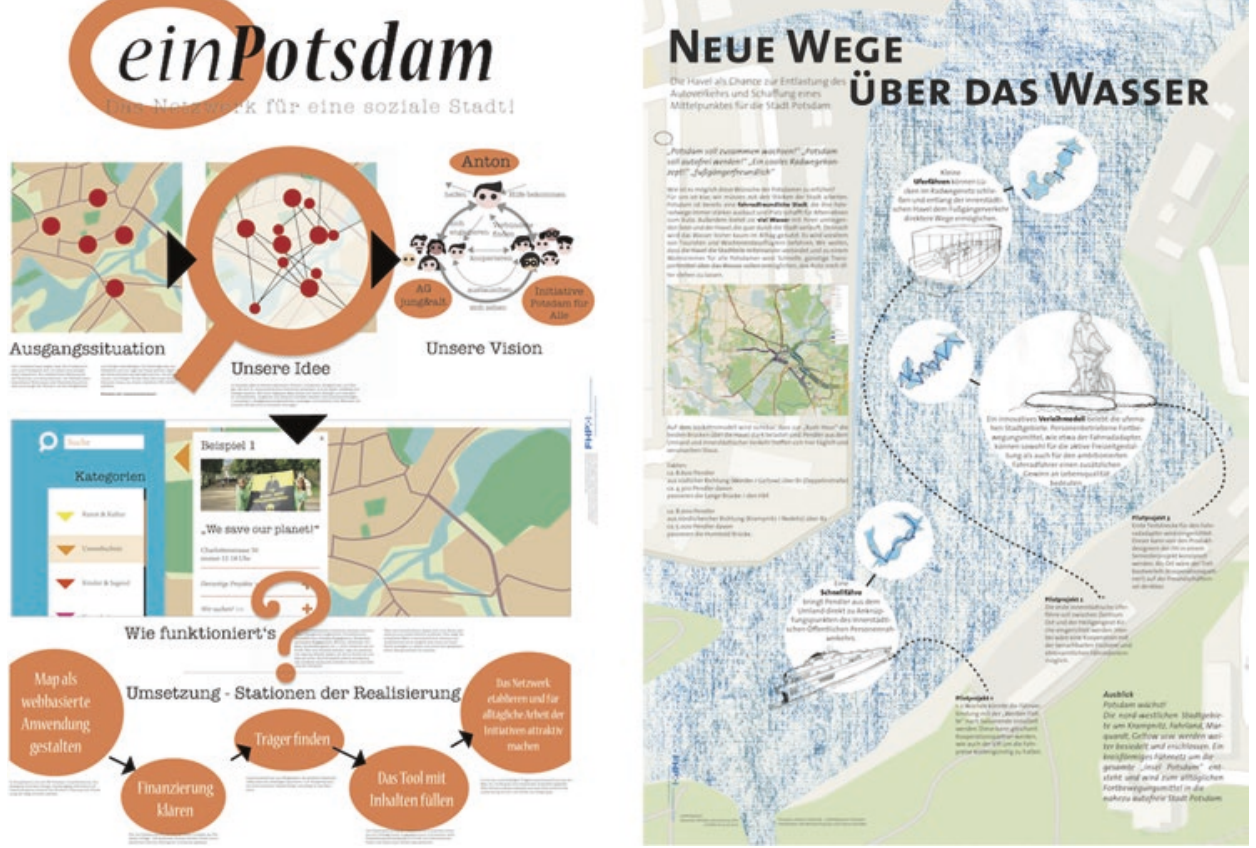

Fig. 11.1 Poster presentations of the results of the seminar. The task of the visualization was to develop a self-explanatory and inspiring project presentation formatted on an A0-size poster containing all of the important information regarding the understanding of the "vision," as well as its implementation. (Source: representation by students at FH Potsdam; left: Manuela Goschy, Lucas Horn, Paulina Kietzell and Stefan Pudellek; right: Johanna Olm and Sebastian Witzke)

- SWOT analyses (a tool for assessing the strengths, weaknesses, opportunities and threats associated with a project),

- Delphi studies (multi-stage expert interview; e.g. Schröder et al. 2011),

- scenario analysis (software-assisted generation of consistent, plausible development paths; e.g. Scholz and Tietje 2002),

- system dynamics models (mathematical description of the variable relationships; e.g. Prytula 2011) or

- agent-based simulation (modeling of agent behavior in the social system; e.g. Wolf et al. 2015).

Students were familiarized with the approach associated with the methods, and for what purposes they are used.

4. Communicating visions: Last but not least, the effective use of suitable media (figures, diagrams, texts and other media) and the empowerment of different perceptual channels of the target groups contribute to the understanding and acceptance of a project. Among other things, there was discussion of the experimental studies through which 
the effectiveness of different ways of communicating a vision for the future within the context of urban development processes was examined (e.g., Shipley and Michela 2006).

\subsection{Didactic, Methodological and Organizational Challenges}

The project course "Visionen Urbaner Zukünfte - Leitbildprozess Potsdam" ("Visions of Urban Futures - Process of Developing a Model for Potsdam") serves as an example of the challenges that accompany inter- and transdisciplinary inquiry-based learning. In our experience, the following organizational and methodological principles have been shown to work (cf. also Mieg et al. 1996; Stauffacher 2001):

(1) Project work in interdisciplinary groups makes results-oriented work possible and does not overwhelm the students with subject-specific detailed knowledge. The project forms the "common thread" in the seminar, along which specialist knowledge, professional and personal competencies, interdisciplinary and complementary perspectives can be imparted. In the above example, the added value of interdisciplinary work lay in particular in studying urban development tasks (strategies for growth or shrinkage processes, demographic change, etc.) both from a planning perspective (spatial structures, building structures and infrastructures) and from a socio-psychological perspective (values, leadership models) using methods associated with futurology.

(2) Good preparation, coordination of learning objectives and working methodology are essential prerequisites for a successful course, in particular when multiple instructors are involved, as is the case with "InterFlex" courses. It is useful to have an elaborated schedule for the respective courses with exact assignments of responsibilities, methods and media used, as well as defined learning and intermediate goals (milestones). It is advantageous if the instructors already coordinate their subject-related perspectives with one another during the preparation and then focus the discussion during the course on concrete questions pertaining to the project work.

(3) Early involvement of practice partners in the design of the seminar and in implementing the course itself has proven to be successful, e.g. through lectures or guest reviews. Practice partners can present real problems from a mostly non-academic perspective. The involvement of practice partners requires a degree of coordination and preparation time that should not be underestimated. Here, binding appointments and a clarification of the respective expectations and roles are helpful.

(4) Field visits or excursions have proven to be very beneficial for the learning process. In addition to a practical view, these offer in particular the opportunity for students to meet each other amongst themselves, as well as for students and instructors to interact with one another in an informal way. An excursion allows the group to have shared, holistic experiences and fosters communication within the group since its activities include concrete organizational tasks must be solved. The shared experiences can be referenced in later discussions. 
(5) Finally, one should not have unfulfillable expectations of the results of the seminar. Frequently, only limited relevant research results can be obtained within the framework of a university course, in particular due to students' limited time resources.

"Failure" also sometimes provides useful learning outcomes. Any experience can be considered a useful one if it prompts new insights and actions. Often, however, new incentives and ideas emerge in inter- and transdisciplinary teaching contexts that can then inspire the instructors' research program. In addition, teaching in the InterFlex format offers the opportunity to try new research ideas in a low-threshold way.

\subsection{Theses on Inquiry-Based Learning in the Context of Inter- and Transdisciplinarity}

Finally, we would like to present our experiences and our reflections on inquiry-based learning within the context of inter- and transdisciplinarity in the form of three theses.

Thesis 1: Inter-and transdisciplinarity require a new unity of teaching and research.

Classifying courses as non-research-oriented "compulsory or basic subjects" (usually with a focus on lecturing-centered teaching methods) and "inquiry-based learning" is not (or no longer) up-to-date in terms of a successful transfer of knowledge and preparation for professional practice according to the common thesis of the present volume. This especially applies to inter- and transdisciplinary research and teaching topics. In a society that is permeated with "wicked problems" (see above), in practice, every problem solution constitutes a research process. As such, the integration of interdisciplinary knowledge and the reduction of uncertainty with respect to the pure application of secured disciplinary knowledge are the central challenges. It is therefore very important to confront students with uncertain knowledge, or different or deviating knowledge and positions, so that they can practice the ability to independently assess complex issues.

Therefore, the development and training of competencies for problem-solving strategies as well as knowledge, project and group management should be a priority in inter- and transdisciplinary teaching. It is more expedient to confront students with complex problems and issues derived from those problems, the solution to which then requires that content and methodology be learned. Here, educators provide support, but there is a certain dissolution of the traditional role relationship. Although educators may have a head start in terms of experience, they are fundamentally faced with the same challenge as the students when faced with complex "wicked problems" and the limitations of their own knowledge. Interdisciplinary and transdisciplinary educators and researchers are also constantly in the position of having to acquire new, unfamiliar knowledge and thus are able to serve as "somewhat more advanced" role models for students instead of as authoritative mediators of knowledge. 
Thesis 2: Inquiry-based learning can serve as a testing ground for larger innovation processes.

As a learning institution, a university as a whole must be able to transform itself and adapt to changing technological, ecological, and socio-economic challenges. To this end, inquiry-based teaching offers a suitable testing ground and learning arena in order to develop innovations in a manageable learning context. At the same time, by involving practice partners, requirements from society, the economy, and the development of technology can be brought directly into the university. In the long run, ideas for new content concepts or organizational forms for bachelor's and master's degree programs may be created as a result, for example with networked, interdisciplinary courses, which help to secure the quality and innovative capacity of the university.

Course-immanent and inter-semester tools for quality control and improvement must be implemented in the courses themselves. These include, inter alia, appropriate forms of teaching evaluation or peer feedback, both between students and between educators. Thus, the adaptability of the teaching concepts can be facilitated within the seminar itself as well as across semesters. Inquiry-based teaching can be represented by the image of a developmental spiral, where both individual and organizational-structural development continues to occur. "Errors" and "failure" cannot be ruled out in innovation processes and must also be allowed in innovative teaching formats.

Thesis 3: Inquiry-based learning can act as a catalyst on the development of applicationoriented research collaborations.

Inquiry-based teaching can serve as a building block in the strategic development of research projects, when courses are used either as a starting point for, in support of, or as a complement to research projects. Interdisciplinary courses can be used as a basis for identifying additional research activities or to support such activities by adding depth.

Inquiry-based teaching can be excellent for initiating practice collaborations and for exploring research topics. Ideally, this creates win-win situations for the practice partners, who can benefit directly from the results of practice-oriented project work, and who are therefore motivated to engage in further collaboration, but also for the students, due to the practical instruction.

\section{References}

Ammann, B./Bartl, D./Cartes, S./Klose, B. (Hrsg.). (2013). InterFlex - Querdenken erwünscht: Interdisziplinär und forschend lernen. Fachhochschule Potsdam.

Landeshauptstadt Potsdam (2015). Potsdam weiterdenken. Leitbildprozess der Landeshauptstadt Potsdam. Retrieved 30 October 2015 from https://www.potsdam-weiterdenken.de/

Mieg, H. A./Evetts, J. (2019). Professionalism, science, and expert roles. In K. A. Ericsson/R. R. Hoffman/ A. Kozbelt/A. M. Williams (Hrsg.), The Cambridge handbook on expertise and expert performance (2nd ed., pp. 127-148). New York: Cambridge University Press. 
Mieg, H. A./Hübner, P./Stauffacher, M./Bösch, S./Balmer, M. (Hrsg.). (2001). Zukunft Schiene Schweiz II: Ökologisches Potenzial des Schienengüterverkehrs am Beispiel der Region Zugersee, Fallstudie 2000. Zürich: Rüegger.

Mieg, H. A./Scholz, R. W./Stünzi, J. (1996). Das Prinzip der modularen Integration: Neue Wege von Führung und Wissensintegration im Management von Umweltprojekten. Organisationsentwicklung, 15(2), 4-15.

Nanus, B. (1992). Visionary leadership: Creating a compelling sense of direction for your organization. San Francisco: Jossey-Bass.

Prytula, M. (2011). Ein integrales Energie- und Stoffstrommodell als Grundlage zur Bewertung einer nachhaltigen Entwicklung urbaner Systeme. Dissertation an der TU Berlin, Universitätsverlag der TU Berlin. Retrieved 30 October 2015 from https://depositonce.tu-berlin.de/handle/11303/3425

Schneidewind, U./Singer-Brodowski, M. (2014). Transformative Wissenschaft. Klimawandel im deutschen Wissenschafts- und Hochschulsystem (2. verbesserte und aktualisierte Auflage). Marburg: Metropolis-Verlag.

Scholz, R. W./Tietje, O. (2002). Embedded case study methods: Integrating quantitative and qualitative knowledge. Thousand Oaks: Sage.

Schröder, T./Huck, J./de Haan, G. (2011). Transfer sozialer Innovationen. Eine zukunftsorientierte Fallstudie zur nachhaltigen Siedlungsentwicklung. Wiesbaden: Springer VS.

Shipley, R./Michela, J. L. (2006). Can vision motivate planning action? Planning, Practice, \& Research, 21, 223-244.

Stauffacher, M. (2001). Fallstudiendidaktik: Die Steuerung von gruppendynamischen Prozessen in einem transdisziplinären Lehrprojekt. In H. A. Mieg, P. Hübner, M. Stauffacher, S. Bösch/ M. Balmer (Hrsg.), Zukunft Schiene II: Ökologisches Potenzial des Schienengüterverkehrs am Beispiel der Region Zugersee, Fallstudie 2000 (S. 217-228). Zürich: Rüegger.

Wissenschaftsrat (2015). Zum wissenschaftspolitischen Diskurs über Große gesellschaftliche Herausforderungen. Positionspapier. Retrieved 15 October 2015 from http://www.wissenschaftsrat.de/download/archiv/4594-15.pdf

Wolf, I./Schröder, T./Neumann, J./de Haan, G. (2015). Changing minds about electric cars: An empirically grounded agent-based modeling approach. Technological Forecasting and Social Change, 94, 269-285.

Open Access This chapter is licensed under the terms of the Creative Commons AttributionNonCommercial-NoDerivatives 4.0 International License (http://creativecommons.org/licenses/bync-nd/4.0/), which permits any noncommercial use, sharing, distribution and reproduction in any medium or format, as long as you give appropriate credit to the original author(s) and the source, provide a link to the Creative Commons licence and indicate if you modified the licensed material. You do not have permission under this license to share adapted material derived from this chapter or parts of it.

The images or other third party material in this chapter are included in the chapter's Creative Commons licence, unless indicated otherwise in a credit line to the material. If material is not included in the chapter's Creative Commons licence and your intended use is not permitted by statutory regulation or exceeds the permitted use, you will need to obtain permission directly from the copyright holder.

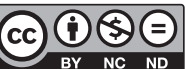

